\title{
School Leadership Theory and Pactice in Times of COVID-19: Our Learnings from a National Webinar
}

\author{
Inbanathan Naicker \\ ORCID iD: $\underline{\text { https://orcid.org/0000-0003-2092-0878 }}$
}

\section{Vitallis Chikoko \\ ORCID iD: $\underline{\text { https://orcid.org/0000-0001-6135-6172 }}$}

\begin{abstract}
While the coronavirus disease 2019 (COVID-19) in South Africa has made visible the adaptability of some schools to effortlessly transition to the "new normal' in terms of school organisation and functionality, many public schools, mainly the under-resourced dysfunctional cohort of schools, have struggled to come to terms with the different conditions. Similar to other developing economies, this is ascribed, in part, to poor school leadership. Although scholarship on school leadership theory and practice in times of a pandemic is non-existent, what is clear is that conventional notions of school leadership will not be useful in navigating schools through this tumultuous, uncertain and volatile period. In this article, we draw on data from a national school leadership webinar to respond to the question: What can be learnt from the webinar on school leadership theories and practices that can make a difference to school functionality in the context of COVID-19? In this qualitative study, we purposively selected the presentations of four academics in education leadership and two practitioners, one, a school principal and the other a circuit manager. We drew on a grounded theory approach and inductively analysed the narratives of the participants. Our findings on what promotes functional schools in times of a pandemic seem to point to school leadership theories and practices that support school resilience; that foster an ethic of collective care; and those that scaffold a reculturing and restructuring of school spaces. Drawing from our findings,
\end{abstract}


we offer liberation school leadership (LSL) as a proactive leadership approach to assist schools in times of crises.

Keywords: distributed leadership, ethic of care, liberation school leadership, resilient leadership, self-directed learning

\title{
1 Contextualising our Research
}

\author{
If we lead today's schools \\ as we led yesterday's, \\ we rob children of a better tomorrow. \\ (A recasting of John Dewey's profound words.)
}

In South Africa, there is growing scholarship that lends credence to the country having a dual public education schooling system, linked historically to the legacy of apartheid. Within this bifurcated schooling system, the wealthiest minority of learners (primarily belonging to the white population) attend well-resourced, functional schools while the impoverished majority of learners (predominantly black) attend under-resourced, dysfunctional schools (Bisseker 2019; Christie 2020; Maringe \& Sing 2019; Spaull 2012). The COVID-19 contagion officially recognised as a pandemic by the World Health Organization (WHO) and declared a national disaster by the South African government since March 2020, is not only just a health emergency (Reyburn 2020). It has, for example, impacted our already divided schooling sector in multiple ways and may have possibly transformed the way we consider delivering education in the future (Hooge \& Pont 2020; Reyburn 2020). It has radically changed our schooling landscape, generating particular effects in both the well-resourced, functional schools and underresourced, dysfunctional schools. More importantly, it has exposed the latent fractures and inequities in basic public education from early childhood development level to Grade 12 (the exit point from basic education). It has made visible the adaptability of the well-resourced schools to effortlessly transition to alternate pedagogies while simultaneously exposing the digital divide and the digital poverty that besets many of the under-resourced schools in the country (Black et al. 2020; Coughlan 2020). Many of the 


\section{Inbanathan Naicker \& Vitallis Chikoko}

poorly resourced schools struggled to come to terms with the new normal. Consequently, schooling for the majority of learners came to a halt during the height of the lockdown in South Africa (Black et al. 2020). While structural inequalities are to blame for those who buy into victimhood discourses of schooling in South Africa, poor leadership is often seen as the elephant in the room for those who subscribe to empowerment discourses of schooling in the country.

Although scholarship on school leadership theory and practice in times of a pandemic is non-existent (Harris 2020; Harris \& Jones 2020), what is abundantly clear is that conventional notions of school leadership will not be useful in navigating schools through this vulnerable, tumultuous, uncertain and volatile period of the pandemic. Hence, we need to rethink school leadership; we need to reimagine school leadership (Hynes 2020). It is only 'in times of great disruption and change' such as the unprecedented effects of COVID-19 that 'opportunities to remake and [re]imagine new forms of equitable education' and school leadership emerge (Nasir \& Bang 2020: par 2). New prospects arise for leaders to deviate from routinised practices and do something different to respond to the changed circumstances that threaten organisational stability. The pandemic should be seen as a portal of transition for organisations (Black et al. 2020). As Harris and Jones (2020: 246) put it, it is about 'being able to navigate a different course' and 'create new pathways' to ensure school functionality. School leaders, therefore, need to think and act innovatively. They should look for new possibilities, novel connections, inventive networks and creative practices in order to respond to the changed structural, cultural and agential conditions prevalent in schools owing to the pandemic (Knight 2013). Given the above, the purpose of this article is to explore leadership theories and practices that may make a difference in the operation of schools as functional organisations during the pandemic. To address this purpose, we draw on the deliberations of a national school leadership webinar titled, School leadership in times of crises: The COVID-19 pandemic hosted by a higher education institution in South Africa as a source of data. Specifically, our purpose in crafting this article is encapsulated in the following key question: What can be learnt from the webinar about leadership theories and practices that can make a difference to school functionality in the context of the COVID-19 pandemic?

The webinar, held on 27th May 2020 using the Zoom video conferencing platform, was organised by the co-author of this article, 
Vitallis, with the assistance of the Corporate Relations Directorate at the university where he is based. The webinar took the form of a panel discussion chaired by Vitallis. The panel comprised six presenters. Four were academics in education leadership, based at higher education institutions in South Africa; one was a school principal and the other a recently retired circuit manager. Each panel member was given about seven minutes to talk to the theme of the webinar from the perspective of their professional influence. The webinar spanned about 90 minutes and included a question-and-answer session of about half an hour. It was well attended with about 50 delegates comprising academics, researchers, school leaders, education officials and teacher union officials. Inbanathan, the co-author of this article was one of the invited delegates.

In this article, we use the term school leadership in two ways. Firstly, we use the term to refer to leaders who occupy formal or informal positions of influence in schools such as teacher leaders, departmental heads, deputy principals and principals (Connolly et al. 2017). Secondly, we use the term to refer to the practice of leading where leaders influence their colleagues in the school community to attain shared goals with the aim of bringing about change and transformation in schools (Connolly et al. 2017; Mertkan 2014). Change and transformation are important concepts during crises such as a pandemic because they enable organisations to reset to a new equilibrium so that organisational stability and functionality can be attained. In foregrounding school leadership in this article, we are cognisant of the linkages of leadership with the related concept of management. While management is about maintaining the status quo of organisations through activities such as planning, organising, controlling and coordinating; sound management practices are often needed to complement leadership practices in order to ensure homeostasis of organisations (Drysdale et al. 2016).

Metaphorically, at schools, many 'leaders are walking a tightrope without a safety net' because '[t]here are no precedents and no guides to leading schools in a pandemic' (Harris \& Jones 2020: 244). Given the dearth of scholarship on leading schools during a pandemic, we see our article as having significance at two levels for educational leadership and management, namely at a theory level and a practice level. From a theoretical perspective, we envisage that the article may draw attention to leadership theories that might be useful in scaffolding practice during these trying times. With regard to practice, the article may alert school leaders, to the strategies, 


\section{Inbanathan Naicker \& Vitallis Chikoko}

moves and manoeuvres that they can harness and deploy in meeting the challenges posed by the pandemic at their schools. The article commences with a brief review of the literature of leadership in times of crises and school functionality. Next, the methodology underpinning the study is explained, followed by a presentation of the findings and a discussion of the findings. In bringing the article to a conclusion, we consolidate our learning by harking back to the key question informing the article, namely, what can be learnt from the webinar about school leadership theories and practices that can make a difference to school functionality in the context of the COVID-19 pandemic?

\section{School Leadership in Times of Crisis and School Functionality}

A survey of the literature on leadership during times of crisis reveals that while there is a steadily growing corpus of literature in fields such as medicine and business, there is minimal scholarship on school leadership in times of crisis (Mutch 2015; Smith \& Riley 2012). There is consensus, across disciplines, in the extant literature that the actions of the leader in times of crisis are vastly different when compared to the actions of the leader during normal circumstances. During a crisis, organisations such as schools will experience systems that fail. The infrastructure, technology and communication systems may become compromised, which could thrust schools into unfamiliar territory (Direen 2017; Mutch 2015). The COVID-19 pandemic did just that. Countrywide, schools had to shut down and online (virtual) schooling (alien to the majority of learners in South Africa), was pursued by schools that had the resources. School leaders found themselves leading learning in contexts they were unaccustomed to, with varying degrees of success.

Leadership in times of crisis is about being proactive and being able to identify possible threats to the effective functioning of the school. School leaders need to put in place mechanisms to mitigate the risks so that the school remains functional, and once the crisis is over the school can return to a state of normality (Mutch 2015). Unfortunately, for the majority of dysfunctional schools in South Africa, school leaders were not able to effectively deal with the repercussions of the pandemic on their schools (Black et al. 2020). 
When dealing with crises, Smith and Riley (2012: 64) advise school leaders to be transgressive in their approach:

A crisis is a major test [for school] leadership .... Leaders need to take responsibility, and do what needs to be done. Forget the rules. Rules are for normal times. In a crisis, do whatever needs to be done as quickly as you can possibly do it - even if it means breaking 'the rules'!

Mutch (2015) posits that three key factors influence leadership in crisis contexts - dispositional factors, relational factors and situational factors. Dispositional factors refer to what leaders bring to the crisis in terms of their personal and professional attributes. Drawing on Bourdieu (Lingard \& Christie 2003), this is the habitus of leaders, i.e. attributes they have developed from their lived experiences which serve as assets they can deploy in times of crises. Relational factors refer to how leaders build a collective vision of community in the organisation, build trusting relationships and foster collaboration. This is about growing cohesive teams within an organisation and 'work[ing] with and through people to achieve critical [organisational] outcomes' (Smith \& Riley 2010: 65). Situational factors refer to how leaders assess the crisis, their decision-making, deployment of resources, creative thinking and constantly re-appraising options. Put differently, leaders will need 'a strong capacity to think laterally; a willingness to question events in new and insightful ways; a preparedness to respond flexibly and quickly and to change direction rapidly if required' (Smith \& Riley 2010: 65).

\section{Methodology}

This study is an interpretive, qualitative inquiry. We align with an interpretive perspective and qualitative approach for two reasons. Firstly, we concur that understanding and meaning-making of phenomena is a subjective experience, and is based on how participants (in our study the webinar presenters) see the world and the meaning they ascribe to it (Reeves \& Hedberg 2003). Secondly, we agree that how we know or come to know phenomena is the result of social interaction (Mertens 2005). Hence, we subscribe to the notion that generating knowledge from a webinar is the result 


\section{Inbanathan Naicker \& Vitallis Chikoko}

of our interaction as researchers with the presentations of the participants.

As we stated previously, the webinar titled School leadership in times of crises: The COVID-19 pandemic was our source of data. We purposively selected all six presentations from the webinar as data sources. Purposive sampling is about the deliberate selection of information-rich sources (Saunders et al. 2012), and we considered all six presentations as having relevant information for the focus and purpose of our study. The six participants represented different areas of expertise in education leadership. Four participants were from academia and had experience in school leadership theory, practice and research. They were Pieter, a senior academic and researcher at a university in Gauteng; Norma, an early career academic at a university in KwaZulu-Natal; Fred, a senior academic and researcher at a university based in Gauteng; and Anne, a head of department at a university in the Eastern Cape. To complement the four academics, there were two practitioners - John, a recently retired circuit manager in KwaZulu-Natal and Zamani, a school principal at a township primary school in KwaZuluNatal.

Each of the participants' presentations at the webinar served as a data source. The webinar was recorded to the Zoom cloud by the organisers and thereafter downloaded and shared with the delegates. We transcribed the recording and thereafter subjected the transcription to inductive thematic analysis. Thematic analysis is about 'identifying, analysing, organising, describing, and reporting themes found within a data set' (Nowel et al. 2017: 2). An inductive, grounded approach to the analysis allowed for the data to 'speak to us' rather than us generating a priori categories and then imbricating the categories onto the transcript (Gabriel 2013). In so doing, we became 'the instruments for analysis, making judgments about coding [and] theming' and reflexively engaging in 'decontextualising, and recontextualising the data' in keeping with the focus and purpose of our study (Nowel et al. 2017: 2). Further, the grounded theory approach persuaded us to develop theory from rigorously analysing the empirical evidence (Charmaz \& Belgrave 2015). Through iterative and recursive comparison of the codes and themes that emerged from the participants presentations, we were able to look for consistencies and differences in the data and draw theoretically relevant threads from them to generate theory (Chun Tie et al. 2019).

From a research ethics perspective, procedural ethics was ensured by gaining the consent of the six presenters to use their presentations for re- 
search purposes. Ethics in practice, with special emphasis on relational ethics, was upheld by using nom de plumes to anonymise the identities of the presenters (Ellis 2007; Guillemin \& Gillam 2004). With regard to the findings of the study, we acknowledge that they do not have wide-ranging generalisability. Nonetheless, we seek solace in the metaphor that some of the findings may serve as 'a dewdrop in which the world [of theory and practice of school leadership during a pandemic] is reflected' (Maree 2007: 76).

\section{Findings}

The findings of the study are presented thematically below.

\subsection{Leadership in a Context of Presence and Absence: 'We have teaching which is disembodied'}

Presence and absence are states of being. The COVID-19 pandemic has accentuated these two states of being in terms of site-based and remote schooling. Anne explained in terms of remote teaching and learning the disconnect between presence and absence:

Those who are present are not wholly present because the images are distorted ... disfigured ... disjointed mugshots ... We have teaching which is disembodied ... Absence of physical bodies ... absence of energy ... there are discordant connections through disturbances ... absences as a consequence of limited data and poor connectivity ... learners and teachers [educators] experiencing Zoom fatigue.

Anne continued by clarifying absence and presence in terms of site-based schooling and what this means in terms of learners and teachers:

Limited presence ... reduced number [of] learners present ... Absence of learners whose parents have decided they should home school ... For those who are present, mask wearing and social distancing becomes the norm ... no after school activity .... as time passes there will be an absence of learning and teaching as learners and teachers [educators] become infected. 


\section{Inbanathan Naicker \& Vitallis Chikoko}

The COVID-19 pandemic has given rise to a 'pandemic pedagogy' characterised by the rapid move to online education by schools that have the resources to do so (Fataar \& Badroodien 2020: 2). While this transitioning is meant to ensure the continuation of teaching and learning in the face of the pandemic, which sound instructional leadership supports (Backor \& Gordon 2015), it is nevertheless regarded as a mode of teaching and learning which is sometimes characterised as being disjointed and disembodied. Teaching is fundamentally recognised as an activity of building relationships with learners and is seen as an embodied activity encompassing the socioemotional connectedness of the teacher and learner (hooks 1994; Nieto 2003; Will 2020a). The challenge for school leaders in their leadership for learning, is not only about being technologically savvy in terms of online pedagogies (Harris \& Jones 2020), it is also about getting their teachers and learners to build a sense of community which promotes their socio-emotional connectedness (Coughlan 2020; Rose \& Zambrano 2020). This is an integral component of the relational factors, referred to elsewhere in the article, which Mutch (2015) advises as being important in negotiating crises. More importantly, to prevent absences, school leaders also need to ensure that there is reliable virtual connectivity among teachers and learners since a stable and dependable internet connection is key to delivering high quality online learning (Rose \& Zambrano 2020).

For those learners who do not have the resources for online learning, school leaders have to ensure that teaching and learning continue for the learners who are physically present at schools in a safe and secure manner (United Nations Educational, Scientific and Cultural Organization or UNESCO) 2020). School leaders are instructed to ensure that they '[p]rotect the value of classroom teaching and learning and the invaluable face-to-face interaction between the teacher and learners' (Department of Basic Education (DBE) 2020: 13). Notwithstanding, the DBE's efforts to ensure safe spaces for site-based learning, an amendment to the Disaster Management Act, 57 of 2002 granted parents who felt anxious about the safety of their children at schools the option to keep their children at home, provided they met certain conditions (Republic of South Africa (RSA) 2020). The implementation of this de jure absence of learners meant the addition of another layer of responsibility for School Management Teams (SMTs) because they had to capacitate parents around the protocols of home schooling. An added dimension of absence was raised by the presenter Anne, 
in relation to teachers aged 60 years and over, and those with chronic underlying medical conditions termed comorbidities. While policy granted these teachers the concession of working from home (Education Labour Relations Council (ELRC) 2020), the schools, however, were not allocated replacement teachers to cover the workload of the teachers working from home. School leaders were thus thrust in a human resource deployment predicament because given the physical distancing of learners, class units had to be increased while the number of teachers decreased. Thus, from a human resource utilisation perspective, school leaders have to do more with less staff. The presenter, John took the issue of absence a step further by posing the following conundrum: 'What happens when the school principal has comorbidities? .... Is a new leader appointed to the school?' Since there is no replacement staff, some affected school principals - instead of requesting their School Governing Bodies (SGBs) to appoint a senior SMT member to deputise as principal - refused to relinquish the 'leadership reins' and opted to lead schools by 'remote control'. The school principals issued directives to school leaders on the plant from the comfort of their abodes in the hope that their school remained functional.

\subsection{Leadership as 'an ethic of collective care'}

The spreading of the pandemic has increasingly thrust school leadership into spaces where decision-making around teaching and learning had to be juxtaposed against issues of welfare care and socio-emotional care. The UNESCO (2020) report (2020) pays particular attention to the issue of the staff and student care during the pandemic, pointing to issues of mental health and socio-emotional support. Norma clarified that 'Leaders are faced with competing priorities that have never been traded-off before .... Which one takes precedence?' School leaders are thus plunged into dilemmatic spaces where difficult choices need to be made (Fransson \& Grannäs 2013). In order to make transparent what is at stake, and the competing options that need to be presided upon, Anne indicated:

Leadership work during and post the pandemic ... will need to be reconceptualised as 'an ethic of collective care', characterised as welfare care and pedagogical care .... As the [novel corona]virus spreads in schools, school leaders will be called upon to take account 
of the whole person ... of staff and learners' wellbeing, health and psychological needs over the pedagogic needs ... pastoral and welfare care will be foregrounded and pedagogic care backgrounded.

John and Norma seemed to agree with Anne's thinking on the positioning of curricular needs and socio-emotional needs. John and Norma respectively explained:

Focusing solely on curriculum catch-up can be dangerous because this is an unnerving time for both teachers and learners ... psychosocial services during this uncertain time is [are] needed.

The educators seem to be focused on how important the socioemotional needs of students [learners] and staff are. Hence, these needs need to be addressed before the intellectual needs of students [learners] can be addressed.

School leaders will have to make complex decisions in short spaces of time (Will 2020b). In operationalising the decision-making process, the dispositional attributes of the school leader, her/his relational connectedness with the school community and situational appraisal of what is at stake becomes significant in negotiating a way forward (Mutch 2015). To compound matters, Pieter pointed out that the data to make such decisions may not be available owing to the novelty of the pandemic. The SMTs will thus have hard decisions to make where they may have to sacrifice teaching and learning so that welfare care and socio-emotional care are given priority. Hyness (2020: 1-2) contextualises the issue of care and the decision-making around it by advising that the attention of school leaders may need to "shift 180 degrees, from obsessing over test scores and accountability to an entirely different paradigm of physical, mental, and emotional wellbeing for students and staff'. Further, in South Africa, many families live in abject poverty. For these families, 'schools are not only spaces where learners access knowledge, it is in many cases understood as a space for sustenance, where learners' thirst and hunger for both knowledge and food are quenched' (Du Preez et al. 2020: 3). Hence, during the pandemic, SGBs and SMTs need to ensure that welfare services such as the National Schools Nutrition Programme continue unabated. 
Often, in times of crises, school leaders sacrifice their own wellbeing to care for others. While care for others (in all its forms and manifestations) is a significant attribute of effective school leaders, care of the self, of the leader should not be relegated to the periphery. School leaders should, during and post the COVID-19 pandemic, prioritise 'their own health and wellbeing first, so that they will be able to help others' (Harris \& Jones 2020: 245). Batters (2011: 4), drawing on Foucault's notions of self-care, explains that 'self-care occurs at the bodily, mental and spiritual level'. School leaders thus need to ensure their holistic wellbeing so that they can positively influence the lives of others.

\subsection{Drawing on Good Leadership Theory: 'It's time for courageous leadership'}

Prior to the pandemic, 'school leadership operated within known parameters, with clear patterns and rhythms to the school year' (Harris \& Jones 2020: 246). The emergence of the pandemic has transitioned school leaders from the all-knowing masters of their field to one of unknowing and reknowing. An integral part of reknowing is learning about leadership theory that can make a difference in times of crises. Lewin's (1943: 118) maxim that there is 'nothing as practical as a good theory' is a sagely reminder to school leaders that knowledge of good leadership theory is invaluable in guiding leadership praxis. In times of crises, it is expected of sagacious leaders to draw on their knowledge of good theory to scaffold practice. Some of the presenters harked back to leadership theory to emphasise its importance in times of crises. To illustrate, John called for a typology of leadership termed courageous leadership to steer schools through this period.

Everybody in the school is going to look to the principal for leadership ... Principals should ask themselves ... have they plotted a road map for steering through this course and emerging on the other side victorious? ... The principal will therefore have to step up to the plate ... it is time for courageous leadership ... courageous principals with a strong, shared vision.

The pandemic has 'thrown a curved ball' to many school leaders because 'unpredictability and uncertainty' currently underpins school leadership 


\section{Inbanathan Naicker \& Vitallis Chikoko}

practice (Harris \& Jones 2020: 246). Hence, John is advocating for school principals to embrace courageous leadership since courageous leaders see crises and turbulence as an opportunity to grow and improve their organisations (Gavin 2020). Fred presented an alternative leadership framework labelled resilient leadership to negotiate the pandemic in schools. He explained that 'resilience is the capacity of an organisation, entity or individual to cope with adversity and more importantly attain higher levels of production for the organisation'. He went on to shed light on the following about resilient leadership:

Resilient leaders have an ability to negotiate a crisis ... they are more trusted ... they attract high calibre learners and staff ... they have a strong futuristic view. They have responsive capacity ... adoptive capacity ... adaptive capacity ... transformative capacity. They integrate crisis disaster management into the school curriculum ... they maintain crisis and disaster budgets.

Given the enormity of the tasks that this pandemic has foisted upon school leaders, Anne advocated for a paradigm of leadership that promotes the sharing of responsibilities. She explicated:

Leadership should be seen as a collective activity ... We will [therefore] have no option but to draw on distributed leadership approaches to school leadership.

Given the weight of responsibility and challenges thrust upon school leaders during the COVID-19 pandemic, it cannot be expected that only the formally appointed leaders exercise leadership in a school. Hence, leadership may need to be shared among staff in terms of 'the contours of expertise' prevalent among staff (Crespo 2008: 62). Distributed leadership thus becomes the default response, 'requiring more school leaders, at all levels, to connect, share, learn and network their way' out of the crises imposed by the pandemic (Harris \& Jones 2020: 246). To give gravitas to shared leadership, Fred, when speaking about resilient leadership, also incorporated aspects of distributed leadership into resilient leadership. He emphasised the need to 'prepare and enforce multiple layers of distributed leadership across the school and beyond'. 


\subsection{School Leadership and Social Justice Concerns: 'Provision should be made for the most vulnerable'}

School closures during the pandemic in unequal societies such as South Africa do not have uniform effects on the opportunities for learning and access to knowledge for school children. The pandemic has 'vividly ... [exposed] the fault-lines of the country's inequalities' (Fataar \& Badroodien 2020: 4) or 'societal comorbidities' as Black et al. (2020: 45) enunciate and has made transparent the prospects for learning of the haves and have-nots in South Africa. Some presenters sounded the caveat of the COVID-19 pandemic exacerbating the existing inequities in basic education, and they raised allied social justice concerns. Norma explained in the context of the total shut down of schools during alert level 5 lockdown of the pandemic:

As school buildings are closed, schooling is closed for the majority of learners from poor backgrounds while it is continuing for those from affluent communities ... How do we address this?

Norma's concern is a valid one because this is the reality of our two-tiered schooling system in South Africa. Online learning in South Africa is a privilege of the select few (approximately $8 \%$ of learners) who attend fortified schools, which are generously resourced schools (Black et al. 2020). For the overwhelming majority of the learners who are black and poor and who attend exposed schools, which are severely under-resourced schools, the lockdown during the pandemic meant an absence of meaningful education (Black et al. 2020; Fataar \& Badroodien 2020). The dire consequence of this, as Hargreaves (2020) observes, is the widening of the learning gaps between children from poorer and better-off homes. Hargreaves (2020: par. 10) therefore calls for the engagement of 'counsellors, mental health specialists and learning support teachers to help our weakest learners and most vulnerable children settle down and catch up' when schools re-open. While in many developed countries, this may be the logical route to follow, this may not always be possible in South Africa where finances for education are severely constrained.

Seminar presenter John posed questions around the need for leadership practices that protect the most vulnerable in the communities. He 


\section{Inbanathan Naicker \& Vitallis Chikoko}

proffered: how do the marginalised get their hands-on technology for the continuation of teaching and learning? He thereafter advised:

Invest in school-private sector partnerships that puts technology and data in the hands of poor learners ... provision should be made for the most vulnerable in our society. We need leaders that can do this.

Accordingly, school leaders should see the wider community as partners, as assets and a key resource in leveraging support and protecting the vulnerable in society. Likewise, Harris and Jones (2020) call for the forging of closer relationships with communities in order to mitigate the impact of the pandemic on the teaching and learning of the marginalised and the most vulnerable learners in schools.

Seminar presenter Anne went a step further and lamented the fact that school leader preparation programmes do not train leaders in practices that can alleviate the impact of crises on the vulnerable. She pointed out:

Unfortunately, school leadership and management training do[es] not prepare them for leading during a pandemic ... For example, how do school leaders support families who do not have food? What of orphaned children?

For orphans and vulnerable children, the struggle to learn during prepandemic times (let alone in a pandemic) is in many instances a secondary issue. Priority for these children is food and not data or digital devices (Coughlan 2020). We thus need a cadre of school leaders who understand the impact of food and other related security issues on their learning and ways in which such children could be assisted. School leadership and training programmes will thus require radical rethinking and reconceptualisation so that they remain fit for purpose. A reconfiguration of programmes is required that address leadership skills, practices and actions in times of crises such as the COVID-19 pandemic (Harris \& Jones 2020).

\subsection{A Reculturing and Restructuring of School Spaces: 'Sanitisation before education'}

The COVID-19 pandemic has necessitated a re-culturing and restructuring 
of schools as teaching and learning spaces. Conceiving schools as territorial spaces where particular practices are evident, the pandemic has necessitated new ways of doing things and existing routines reconfigured into new practices in order to adapt to the pandemic. Drawing on Deleuze and Guatari (as cited in Patton 2006), school spaces have to be reterritorialised in keeping with COVID-19 regulations to prevent the spread of the novel coronavirus. Some of the presenters referred to how familiar school cultures and structures had to be made strange owing to the pandemic. Seminar presenter Zamani elucidated how the organisation of classroom furniture and social distancing rules necessitated the rearranging of classrooms and the need for more teachers:

Social distancing requires $1.5 \mathrm{~m}$ between people ... Many schools use a combination desk that is about a metre long ... With social distancing it means that one learner will occupy one desk ... class size will be decreased and this then raises human resourcing issues in terms of who teaches the extra classes.

Pieter validated this issue raised by Zamani by pointing out the domino effect that social distancing in classrooms has on school organisation. He indicated that 'this has staff issues ... and timetabling issues'. Schools, prior to the pandemic, were already contrived spaces where rules and regulations governed the movement of staff and learners, teaching time, allocation of learners and teachers to classrooms, break times and distribution of resources (Jansen 2020). The pandemic has introduced 'measures [that] run counter to how schools usually operate' (Will 2020b: 1) and has changed many of the existing structural and cultural norms of schools which learners and teachers had to acclimatise to at short notice. Some measures outlined by the DBE for SMTs to implement and monitor include physical distancing among learners and teachers and the compulsory wearing of masks to cover the nose and mouth (DBE 2020).

School hygiene practices also needed to be revised to cater for frequent sanitisation of classroom surfaces and learners' hands (DBE 2020). Pieter, drawing on the apartheid era slogan popularised by liberation movements in South Africa of 'liberation before education', explained that the new mantra in schools is now 'sanitisation before education'. Endorsing the need for schools to be safe and sanitised spaces, Zamani explained: 
The school environment needs to be safe for learners ... school leadership must ensure learners are safe ... learners need to sanitise and wash [their] hands regularly.

John explained how school leadership practices need to adapt to the 'new normal'. He elucidated how social media can be brought into the communication space between principal and staff so as not to compromise physical distancing.

There needs to be new ways of doing things ... for example, there is no need for the physical morning briefing of staff anymore. The principal can do this using technology such as a WhatsApp [group] chat ....

\section{Consolidating our Learning}

To borrow from Ivan Illich's famous book Deschooling Society, the COVID19 pandemic deschooled societies across the world. This, 'the age-specific, teacher-related process of requiring full-time attendance of an obligatory curriculum' (Illich 1971: 25-6) at an institution called a school was closed for many learners. We have earlier in this article referred to the poorly resourced public schools in South Africa, the majority of which are dysfunctional. From the webinar, we learn that to all intents and purposes and as was to be expected, learning in the majority of these schools came to a halt upon the advent of COVID-19, the antithesis of the United Nations (UN) 2030 pledge to leave no child behind (UN 2015). We argue that this was the case, not so much because of what the schools could not do during the pandemic, but what they have not been doing all along even before the pandemic, namely, exercising liberation school leadership (LSL), a theory we have developed out of our learning.

In LSL, the school shifts from concentrating on teaching to facilitating self-directed learning (Rocha \& Sanudo 2020) on the part of the learner. We argue that the major reason why learning summarily stopped in the majority of public schools was that learners did not and still do not know how to self-learn. There is a dearth of functional literacy among many learners in South Africa's public schools. This is a social injustice (Rocha \& Sanudo 2020). The LSL starting point is to do the basics: helping every 
learner to acquire functional literacy without which no effective learning can occur going forward. Teachers are often reprimanded or even disciplined for having left their class unattended, in some cases for a few minutes, and then learners engage in unruly behaviour. Granted, teachers must look after the learners entrusted to them, however, we argue that in most cases the deeperseated cause of problems in many a classroom is that learners have no selfdirected learning skills (Naicker 2019). The status quo in schools is that the teacher must always be present to direct learning. The net effect is that both the teacher and the learner are enslaved in the classroom; they are not liberated (Illich 1971). This largely explains why many teachers want to be out of their classrooms at the slightest opportunity and why learners do not feel apprehensive if for some reason they have not gone to school on a particular day.

In LSL, it is not enough for a teacher to be able to deliver learning content and create a secure environment; they must have the knowledge and skills to help learners to develop into self-directed learners. In our experience of continuous professional development of teachers in South Africa, such knowledge and skills are often taken for granted and therefore left undeveloped. Not only should teachers develop such skills in their learners, they must also be continuous self-directed learners themselves. To be a useful member of a professional learning community (PLC) (Wenger 1998), the starting point should be one of the teachers successfully self-directing their own learning. It is liberating to add value to one's PLCs. This brings to the fore the importance of sound leadership on the part of the SMT, particularly the departmental heads in this case.

It is not enough for individual teachers to develop knowledge and skills regarding how to help learners self-learn, rather, it must be a school culture. This underscores the importance of the school principal's leadership. To liberate him/herself and become an LSL leader, the school principal needs to be a life-long learner. Thus, LSL is about developing the school as a community of leaders. This is consistent with the notion of resilient leadership as well as distributed leadership that came up quite strongly in the webinar. It also sits well with the importance of leadership development, another of the emerging strategies recommended. But how would LSL help during a time of crisis? We turn to this in the coming paragraphs. We are working on the premise that COVID-19 is not going to be the last crisis schools will face. The more this pandemic evolves, the more urgent it will 


\section{Inbanathan Naicker \& Vitallis Chikoko}

become for schools to begin implementing LSL.

Without downplaying the importance of the need for resourcing the under-resourced schools, we argue that poor as they may be, schools must develop the courage to move out of the victimhood mode. They must mobilise resources from within their institutions (Kretzmann \& McKnight 1993). In a postgraduate class, a student who had undertaken practical teaching in a no-fee school reported that parents were unwilling (perhaps unable) to make even the smallest financial contribution to the school. However, when learners were required to pay R50 each for a school excursion, all of them did pay. On the excursion day, learners arrived with sophisticated smartphones, which needless to say, like all children, they knew how to use. This same cell phone which for understandable reasons is usually prohibited at school - but a piece of technology which every learner and every teacher possesses - could be a useful learning gadget during the 'deschooled' period and beyond. With adequate functional literacy, learners could be assigned tasks from their textbooks or elsewhere to work on and communicate with their teachers through an application such as WhatsApp, which is relatively cheap and often available, even in areas where network connectivity is weak. Through this approach, learning can happen daily (Annamalai 2019).

Through simple applications like WhatsApp, learners could form what Illich (1971) termed learning webs. These are essentially learning groups formed according to specific needs. Examples could include subject groups, especially in high school, groups of friends, inter-school groups, and so on. Learning from webpages, Facebook, blogs and others (Collins \& Halverson 2018), learners can learn as well as enjoy the connectivity which such platforms bring. In the process, they self-direct their learning. Leadership, listening and other skills develop while learners stay in their homes and therefore, are secure from the threat of the pandemic. Such work would, of course, require meticulous leadership at the various levels in the school.

\section{Conclusion}

Out of the webinar, we see a call for resilient leadership, one for distributed leadership, a call for courageous leadership, a need for leadership development, the need for community involvement in helping the school to cope with 
the pandemic, a call to ensure the welfare of everybody in the school and a call to ensure the prevention of the spread of the disease, among others. There need to be new ways of 'doing' as one webinar panel member argued. As we see it, the mother of all calls encapsulated in all these is one of the school liberating itself from victimhood. We argue that the vehicle of such emancipation is LSL. A school practising LSL is well equipped to successfully forge school-community partnerships. All the calls emerging from the webinar are consistent with LSL. The hallmark of LSL is the development and practising of knowledge and skills which the learner, teacher, departmental head, deputy principal and school principal need to individually and collectively self-learn. A crisis such as COVID-19 is a time to exercise such knowledge and skills; though it is not the best time to start learning the same. We contend that very little learning if any, happened during the first months of the COVID-19 pandemic in most under-resourced public schools in South Africa because of the absence of LSL. We proffer further that LSL is implementable, even in the most under-resourced of schools.

\section{References}

Annamalai, N. 2019. Using WhatsApp to Extend Learning in a Blended Classroom Environment. Teaching English with Technology 19,1: 3 20.

Backor, K.T. \& S.P. Gordon 2015. Preparing Principals as Instructional Leaders: Perceptions of University Faculty, Expert Principals, and Expert Teacher Leaders. NASSP Bulletin 99,2: 105 - 126. Available at: https://doi.org/10.1177/0192636515587353

(Accessed on 27 August 2020.)

Batters, S.M. 2011. Care of the Self and the Will to Freedom: Michel Foucault, Critique and Ethics. Senior Honours Projects. Paper 231. Available at:

http://digitalcommons.uri.edu/srhonorsprog/231http://digitalcommons. uri.edu/srhonorsprog/231

(Accessed on 31 August 2020.)

Bisseker, C. 2019. IMF Report Slams SA's Education Folly. Available at: https://www.businesslive.co.za/fm/features/2019-03-21-imf-reportslams-sas-education-folly/ (Accessed on 2 August 2020.) 
Black, S., C. Spreen \& S. Vally 2020. Education, COVID-19 and Care: Social Inequality and Social Relations of Value in South Africa and the United States. Southern African Review of Education 26,1: 40 - 61.

Charmaz, K. \& L.L. Belgrave, 2015. Grounded Theory. Available at https://doi.org/10.1002?9781405165518.wbeosg070.pub2

(Accessed on 2 November 2020.) PMid:26646825

Christie, P. 2020. Decolonising Schools in South Africa: The Impossible Dream. London \& New York: Routledge.

https://doi.org/10.4324/9780367853624

Chun Tie, Y., M. Birks \& K. Francis 2019. Grounded Theory Research: A Design Framework for Novice Researchers. SAGE Open Medicine 7:1

- 8. Available at: https://doi.org/10.1177\%2F2050312118822927 (Accessed on 8 February 2021.)

Collins, A. \& R. Halverson 2018. Rethinking Education in the Age of Technology: The Digital Revolution and Schooling in America. New York: Teachers College Press.

Connolly, M., C. James \& M. Fertig 2017. The Difference between Educational Management and Educational Leadership and the Importance of Educational Responsibility. Educational Management Administration and Leadership 1 - 16. Available at:

https://doi.org/10.1177/1741143217745880

(Accessed on 2 September 2020.)

Coughlan, S. 2020. 'Digital Poverty' in Schools where Few have Laptops.

Available at: https://www.bbc.com/news/education-52399589

(Accessed on 25 September 2020.)

Crespo, M. 2008. Leaderships and Conceptions of Organisation: Contours of

Distributed Conception. Learning Landscapes 1,2:55-71.

https://doi.org/10.36510/learnland.v1i2.254

Department of Basic Education (DBE) 2020. Coronavirus Orientation

Guidelines for Schools. Pretoria: DBE.

Direen, G. 2017. School Leadership in a Post-disaster Setting. SET 2: 9-15.

Available at: https://www.nzcer.org.nz/node/60056

(Accessed on 2 September 2020.) https://doi.org/10.18296/set.0078

Drysdale, L., D. Gurr \& H. Goode 2016. Dare to Make a Difference:

Successful Principals who Explore the Potential of their Role.

International Studies in Educational Administration 44,3: 37 - 53.

Du Preez, P., L. Le Grange, S. Maistry, L. Ramrathan, C. Reddy \& S. Sim- 
monds 2020. Complicated Conversations and Alternative Voices: The SAERA Curriculum Studies SIG on Education Discourses amidst Covid-19. Available at:

http://saera.co.za/wp-content/uploads/2018/03/COVID19-CurriculumStudies-SIG-standpoint.pdf

(Accessed on 27 September 2020.)

Education Labour Relations Council (ELRC) 2020. Collective Agreement 1 of 2020. Centurion: ELRC.

Ellis, C. 2007. 'I just want to tell my story'. Mentoring Students about Relational Writing about Intimate Others. In Denzin, N.K. \& M.D. Giardina (eds.): Ethical Futures in Qualitative Research. Walnut Creak, CA: West Coast Books.

Fataar, A. \& A. Badroodien 2020. Editorial Notes. Special Issue: Emergent Educational Imaginaries during the COVID-19 Pandemic. Southern African Review of Education 26,1: 1 - 5.

Fransson, G. \& J. Grannäs 2013. Dilemmatic Spaces in Educational Contexts - Towards a Conceptual Framework for Dilemmas in Teachers Work. Teachers and Teaching 19,1: 4 - 17. Available at:

https://doi.org/10.1080/13540602.2013.744195

(Accessed on 16 September 2020.)

Gabriel, D. 2013. Inductive and Deductive Approaches to Research. Available at:

https://deborahgabriel.com/2013/03/17/inductive-and-deductiveapproaches-to-research/ (Accessed on 12 September 2020.)

Gavin, M. 2020. 5 Characteristics of a Courageous Leader. Available at: https://online.hbs.edu/blog/post/courageous-leadership

(Accessed on 2 September 2020.)

Guillemin, M. \& L. Gillam 2004. Ethics, Reflexivity, and 'Ethically Important Moments' in Research. Qualitative Inquiry 10,2: 261 - 280. https://doi.org/10.1177/1077800403262360

Hargreaves, A. 2020. What's Next for Schools after Coronavirus? Here are 5 Big Issues and Opportunities. Available at: https://sej.org.uk/whatsnext-for-schools-after-coronavirus-here-are-5-big-issues-andopportunities/ (Accessed on 2 October 2020.)

Harris, A. 2020. Leading a School during a Lockdown. Available at: https://my.chartered.college/2020/04/leading-a-school-duringlockdown/ (Accessed on 2 September 2020.) 
Harris, A. \& M. Jones 2020. COVID 19 - School Leadership in Disruptive Times. School Leadership \& Management 40,4: 243 - 247. Available at: https://doi.org/10.1080/13632434.2020.1811479

(Accessed on 2 October 2020.)

Hooge, E. \& B. Pont 2020. Editorial. School Leadership in Unpredictable

Times. European Journal of Education 55,2: 135 - 138.

https://doi.org/10.1111/ejed.12397

PMid:32508369 PMCid:PMC7264517

hooks, b. 1994. teaching to transgress. New York: Routledge.

https://doi.org/10.3366/para.1994.17.3.270

Hynes, M.J. 2020. After the Pandemic. Our Children Deserve an Education

Revolution. Available at:

https://nycpublicschoolparents.blogspot.com/2020/04/after-pandemicour-children-deserve.html (Accessed on 2 September 2020.)

Illich, I. 1971. Deschooling Society. New York: Harper \& Row.

Jansen, J. 2020. More Eyes on COVID-19: Perspectives from Education Studies: Schools as Organisations and the Science of Re-opening. South African Journal of Science 116, 7/8: 1. Available at:

https://doi.org/10.17159/sajs.2020/8502

(Accessed on 30 September 2020.)

Knight, L. 2013. Not as it seems: Using Deleuzean Concepts of the Imaginary to Rethink Childrens' Drawings. Global Studies of Childhood 3,3: 254 - 264.

https://doi.org/10.2304/gsch.2013.3.3.254

Kretzmann, J. P. \& J.L. McKnight 1993. Building Communities from the Inside Out: A Path Toward Finding and Mobilising a Community's Assets. Chicago: ACTA Publications.

Lewin, K. 1943. Psychology and the Process of Group Living. Journal of Social Psychology 17: 113 - 131.

https://doi.org/10.1080/00224545.1943.9712269

Lingard, B. \& P. Christie 2003. Leading Theory: Bourdieu and the Field of Educational Leadership: An Introduction and Overview to this Special Issue. International Journal of Leadership in Education: Theory and Practice 6,4: 317 - 333. Available at:

https://doi.org/10.1080/1360312032000150724

(Accessed on 2 September 2020.)

Maree, K. 2007. First Steps in Research. Pretoria: Van Schaik. 
Maringe, F. \& N. Sing 2019. School Leadership in Developing Countries. A Case of South Africa. In Bush, T., L. Bell \& D. Middlewood (eds.): Principles of Educational Leadership and Management. $3^{\text {rd }}$ Edition. London: SAGE.

Mertens, D.M. 2005. Research Methods in Education and Psychology: Integrating Diversity with Quantitative and Qualitative Approaches. $2^{\text {nd }}$ Edition. Thousand Oaks: SAGE.

Mertkan, S. 2014. In Search of Leadership: What Happened to Management? Educational Management Administration and Leadership 42,2: 226 242. https://doi.org/10.1177/1741143213499252

Mutch, C. 2015. Leadership in Times of Crisis: Dispositional, Relational and Contextual Factors Influencing School Principals' Actions. International Journal of Disaster Risk Reduction 14: 186 - 194.

https://doi.org/10.1016/j.ijdrr.2015.06.005

Naicker, I. 2019. No-fee Schools in South Africa: Narrative Vignettes of School Leaders' Response to Context. In Chikoko, V. (ed.): Africa Handbook for School Leadership. New York: NOVA.

Nasir, N. \& M. Bang 2020. What we Have Funded and What we Have Learned from our Call for COVID-19 Related Research Projects. Available at: https://www.spencer.org/news/announcing-our-covid-19related-research-grants-awardees (Accessed on 2 October 2020.)

Nieto, S. 2003. What Keeps Teachers Going? New York: Teacher College Press.

Nowel, L.S., J.M. Norris, D.E. White \& N.J. Moules 2017. Thematic Analysis: Striving to Meet the Trustworthiness Criteria. International Journal of Qualitative Methods 16: 1 - 13. Available at:

https://doi.org/10.1177/1609406917733847

(Accessed on 23 September 2020.)

Patton, P. 2006. Deleuze's Practical Philosophy. Symposium 10,1: 285 3030. Available at:

https://philpapers.org/go.pl?id=PATDPP-

4\&proxyId=\&u=http\%3A\%2F\%2Fdx.doi.org\%2F10.5840\%2Fsympos ium200610149 (Accessed on 24 September 2020.)

https://doi.org/10.5840/symposium200610149

Reeves, T.C. \& J.C. Hedberg 2003. Interactive Learning Systems Evaluation. Englewood Cliffs: New Jersey: Educational Technology Publications. 
Republic of South Africa 2020. Department of Basic Education Notice 411, Government Gazette No. 43578, Volume 662. Pretoria: Government Printer.

Reyburn, P. 2020. South Africa: National Disaster Declaration-Now What?

Available at: https://www.mondaq.com/southafrica/government-

measures/911574/national-disaster-declaration-now-what

(Accessed on 2 September 2020.)

Rocha, S.D. \& M. Sanudo 2020. Ivan Illich and Liberation Theology. In

Down, B. \& R. Shirley (eds.): The Sage Handbook of Critical Pedagogies. Available at:

http://dx.doi.org/10.4135/9781526486455.n36

(Accessed on 10 October 2020.)

Rose, D. \& Z. Zambrano 2020. Moving a Summer Program to the Virtual World - While Closing the Digital Divide. Available at:

https://www.edsurge.com/news/2020-07-18-moving-a-summerprogram-to-the-virtual-world-while-closing-the-digital-divide (Accessed on 20 October 2020.)

Saunders, M.N.K., P. Lewis \& A. Thornhill 2012. Research Methods for Business Students. $6^{\text {th }}$ Edition. New York: Financial Times Press.

Smith, L. \& D. Riley 2012. School Leadership in Times of Crisis. School Leadership \& Management 32,1: 57 - 71. Available at:

https://doi.org/10.1080/13632434.2011.614941

(Accessed on 21 September 2020.)

Spaull, N. 2012. Education in SA: A Tale of Two School Systems. Available at: https://www.politicsweb.co.za/news-and-analysis/education-in-saa-tale-of-two-systems

(Accessed on 2 September 2020.)

United Nations (UN) 2015. Transforming our World: The 2030 Agenda for Sustainable Development. New York: United Nations.

United Nations Educational, Scientific and Cultural Organization

(UNESCO). 2020. COVID-19 Education Response. Preparing the Reopening of Schools. Paris: UNESCO.

Wenger, E. 1998. Communities of Practice: Learning, Meaning, and Identity. New York: Cambridge University Press.

https://doi.org/10.1017/CBO9780511803932

Will, M. 2020a. Do you have to 'Love' Every Student? And What if You Don't? Education Week February: 1 - 4. 
Will, M. 2020b. The Socially Distanced School Day. Education Week June: $1-8$.

Professor Inbanathan Naicker

Education Leadership University of KwaZulu-Natal

Durban

Naickeri1@ukzn.ac.za

Professor Vitallis Chikoko

Education Leadership University of KwaZulu-Natal

Durban

Chikokov@ukzn.ac.za 